\title{
Las imágenes monetales Hispánicas como emblemas de Estado
}

\author{
Alicia Arévalo González \\ Universidad de Cádiz
}

\section{Resumen}

El propósito principal de este artículo es valorar las imágenes monetales hispánicas en su condición de emblemas políticos y étnicos para aquellas comunidades que las adoptan. Se analizan primero algunos de los focos iniciales de amonedación, Emporion y Gadir. La Segunda Guerra Púnica y la romanización de la Península abrirán otra etapa, en la que destaca la clara diferencia en las imágenes que proyectan, a través de las monedas, cada una de de las dos provincias hispanas.

Palabras claves: Moneda hispánica, Iconografía, Emblemas políticos, Emblemas étnicos.

\begin{abstract}
The main purpose of this paper is to stress some aspects about the selection mechanism of the monetary types. The choice of the type and its iconography is deeply realet to the political and the etnical ambience of each mint. We analyse some of the first mints, Emporion and Gadir. The secornd Punic war and the romanization of the Peninsula opened a new period in which the monetary types have been differently motivated.

Keywords: Hispanic coinage, Iconography, Political and ethnic emblems.
\end{abstract}

\section{INTRODUCCIÓN}

La cuestión que nos ocupa, las imágenes monetales hispánicas no necesita de argumentaciones para tener conciencia de su interés, un interés que reclama de los investigadores de la antigüedad una atención creciente, al ser, además, una cuestión difícil, con muchas implicaciones y facetas aún no resueltas.

Es sabido que en la puesta en marcha de una emisión monetaria son decisorios varios factores y de ellos es lógicamente reflejo y consecuencia dicha emisión: la autoridad que decide cómo, qué y cuándo amonedar, los receptores inmediatos de las monedas y la finalidad pretendida al poner en circulación las piezas. Es evidente que la autoridad emisora realiza una labor selectiva entre la amplia gama de posibilidades tipológicas influida por sus propios criterios culturales, pero también pensando en la facilidad de ser aceptada por los receptores y en el grado en que se adecuan a la función originaria para la que se han previsto. Pero además, la moneda se convierte pronto para todos, propios y ajenos, en emblema iconográfico de los habitantes y de su territorio. Pues la moneda, tanto por sus tipos iconográficos cuanto por sus sistemas gráficos y códigos lingüísticos, es quizás, más que cualquier otro elemento que podamos considerar, la exhibición palpable de la identidad que la comunidad responsable de su acuñación desea proyectar.

Poco tiempo después de la aparición de la moneda en las costas de Jonia, y coincidiendo con el imparable y rápido proceso de adopción de esta forma peculiar de dinero metálico, la iconografía monetal será muy pronto empleada

\footnotetext{
1 Este trabajo se ha realizado en el marco del Proyecto BHA2001-0187, subvencionado por la DGCYT.
} 

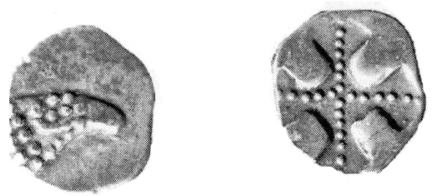

1
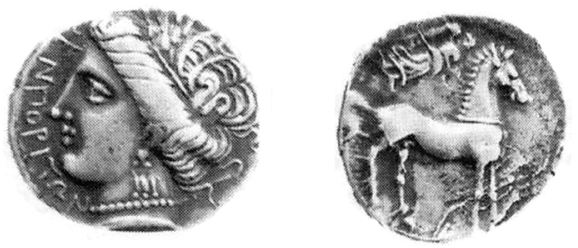

3
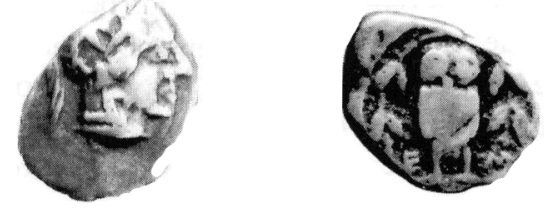

2
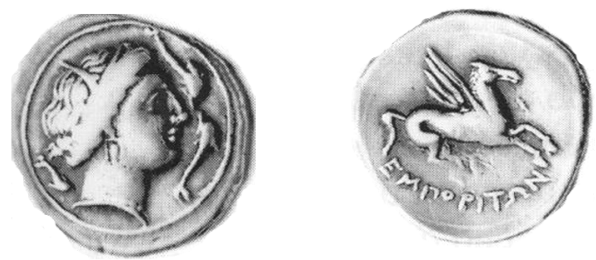

4

Fig. 1: 1. Fraccionaria de Emporion (Ampliada. GNC/MNAC); 2. Fraccionaria de Emporion (Ampliada. GNC/MNAC); 3. Dracma de Emporion (GNC/MNAC); 4. Dracma de Emporion (GNC/MNAC)

como símbolo de autonomía política de las ciudades que la adoptan, convirtiéndose así en verdadero distintivo de las mismas. Con la moneda, los griegos enseñan el valor de los emblemas nacionales. Las ciudades buscan las imágenes de sus divinidades patronas, protectoras de sus productos económicos o los emblemas parlantes del topónimo como en el caso de Egina, primer tipo cívico bien documentado (Kraay, 1976: 43). Pronto esas imágenes locales se convierten en los emblemas políticos de sus ciudadanos. Es más, aunque existen cecas griegas que comenzaron con una preferencia hacia un sistema iconográfico de tipos múltiples, como el caso de los talleres de Asia Menor o de la propia Atenas, con las conocidas monedas blasones o Wappenmünzen (Kroll, 1981: 1-32), cuando captan que la imagen tiene un valor nacional, la fijan y la convierten en emblema. En el caso de Atenas, este hecho se producirá hacia el c.525-520 a.C., momento en el que la ciudad adopta su tipo cívico, que en adelante va a permitir identificar claramente sus emisiones: la efigie de la diosa Atenea y la lechuza (Kraay, 1976: 56-61).

Tal esquema será exportado con éxito, junto con la moneda misma, a los más alejados puntos del Mediterráneo central y occidental como Roma y Cartago, a través de la influencia directa de Magna Grecia y Sicilia. A este proceso monetario, y desde luego también cultural de integración en la koiné helenística mediterránea accederá la Península Ibérica. La diversidad de pue- blos y culturas que la habitan en los inicios de la aceptación del fenómeno monetario hacen previsible unas reacciones diversas y naturalmente una distinta codificación de los mensajes a través de las imágenes presentes en las monedas.

$\mathrm{Si}$ en líneas generales puede afirmarse que conocemos bien el código iconográfico grecorromano, no ocurre lo mismo con los de las otras culturas hispánicas; por si fuera poco, con la significativa excepción de los focos iniciales de la amonedación hispana -Emporion, Arse, Ebusus, Gadir- la documentación numismática que manejamos es, para el caso hispano, de carácter tardío, pues el grueso de las emisiones deben datarse a partir del siglo II a.C. Ello justifica en buena medida la adopción del lenguaje monetario greco-helenístico en muchas de estas acuñaciones que sirvieron al mismo tiempo para describir divinidades que eran indígenas.

\section{LAS PRIMERAS ICONOGRAFÍAS MONETALES de la Península Ibérica}

Antes de analizar como se comporta el grueso de las emisiones hispánicas, conviene antes examinar algunos de esos focos iniciales y, para ello, hemos escogido el caso de Emporion y el de Gadir.

Entre la opción de acuñar tipos múltiplos o adoptar un tipo cívico, Emporion, el primer foco peninsular en emitir moneda a mediados del s. V a.C., va a elegir inicialmente frabricar pequeñas 

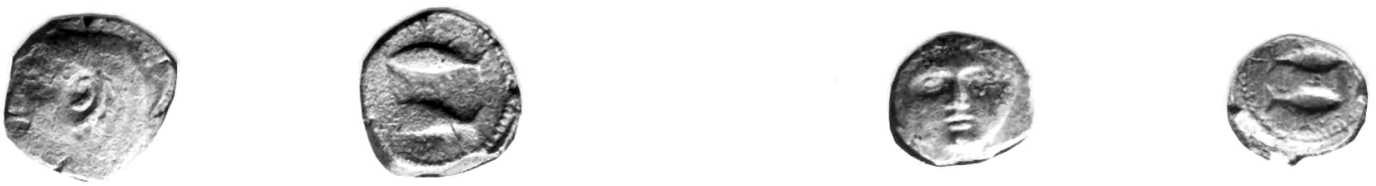

2

1
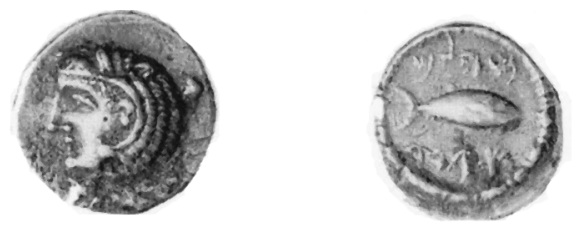

3

Fig. 2: 1. Mitad de Gadir (Torre Alta, San Fernando, Cádiz); 2. Cuarto de Gadir (Torre Alta, San Fernando, Cádiz); 3. Unidad de Gadir (MAN)

fracciones de plata con una gran diversidad de iconografías (Ripollès, 1989: 303-317; Campo, 1994: 75-79; idem, 2003: 25-45; Villaronga, 1997). En esta elección fue decisiva la fuerte conexión con Massalia, la cual va influir de manera muy significativa en las primeras acuñaciones del taller. Emporion elige de entre los muchos modelos massaliotas, la cabeza de carnero y la cruz incusa ( $\left.C N H, 3, \mathrm{n}^{\mathrm{O}} 1-2\right)$, y acuña sin leyenda que la identifique cultural ni territorialmente (Fig.1.1). $\mathrm{Ni}$ si quiera después de rotos los vínculos con Massalia valorará las posibilidades políticas de sus acuñaciones, ya que ahora se inspirará en los nuevos tipos de las ciudades del Mediterráneo central con las que comercia. No será hasta el último cuarto del s. V y el primero del IV a.C., en un momento en que Emporion comercia con Atenas directamente, cuando comienza a dejar constancia de polis al marcar las monedas con las iniciales del topónimo, a pesar de copiar los tipos. Un claro ejemplo de cuanto venimos diciendo es la emisión de Atenea y lechuza rodeada de dos ramas de olivo (Fig.1.2), entre las iniciales $\operatorname{EM}\left(C N H, 4, \mathrm{n}^{\circ} 6\right)$, recientemente analizada por Campo (1993: 31-38). Esta tipología es una copia de los trióbolos de Atenas del siglo $\mathrm{V}$ a.C., la uniformidad del tipo apoya, a juicio de García-Bellido (1993a: 117-149) la hipótesis de que su acuñación sea una respuesta a una necesidad económica fija y en relación con el Ática. Además, la marca de su topónimo en el reverso, y con dos letras al igual que Atenas, implica indudablemente una copia, pero también una decisión de constar como entidad política distinta a la ciudad cuyas monedas reproduce, voluntad política que hasta ahora Emporion no había mostrado. Estamos ante el preludio de lo que constituirá la moneda emblemática de la ciudad, las dracmas con el nombre completo y el Pegaso, si bien éstas fueron precedidas de las dracmas del caballo parado.

En efecto, entre finales del siglo IV e inicios del III a.C. Emporion empieza a acuñar dracmas, donde consta por primera vez la leyenda griega completa EMPORITON junto a nuevos tipos, en el anverso la imagen de una "Aretusa" siracusana para efigiar a Artemis (Pena, 1973: 109-134) $y$, en el reverso encontramos un caballo parado, coronado por una Niké volando $\left(C N H, 17, \mathrm{n}^{\mathrm{O}} 1\right.$ $\left.2,18, \mathrm{n}^{\mathrm{O}} 3-4\right)$, imagen típicamente cartaginesa que nos indica el ámbito comercial al que la ciudad quiere sumarse (Fig.1.3). Pero será ya a mediados del siglo III a.C. cuando Emporion fije sus tipos emblemáticos $\left(C N H, 20, n^{\circ} 12-13,15-\right.$ 17), una cabeza femenina coronada de zarzillos y rodeada de delfines que describe a Artemis de Efeso, divinidad patria de focenses y massaliotas, cuyo culto lo tenemos atestiguado en Ampurias por las fuentes literarias y, la arqueología parece mostrar alguna señal, ya que según Sanmartí (1989: 395-397) existen indicios de que la ciudad contaba con un santuario dedicado a esta divinidad, cuyo culto estaría establecido en un templo arcaico, situado en donde hoy se encuentra la 
iglesia de San Martí, en cuyos cimientos se ha encontrado cerámica griega de comienzos del siglo VI a.C., siendo posible que a este templo perteneciera, según el citado autor, los restos de un friso jónico arcaico con representación de dos esfinges, descubiertos en los primeros años del siglo pasado, no lejos de la iglesia. En el reverso se graba un Pegaso y la inscripción griega EMPORITON (Fig.1.4). Este caballo alado, que en la siguiente emisión se presenta con la variante de su cabeza transformada en el cuerpo de un niño $\left(C N H, 26, \mathrm{n}^{\circ} 61\right)$, podría aludir, como ha defendido Olmos (1992: 107-108), a la fuente que brota en el lecho del amor de un dios marino con una ninfa local. Ambas imágenes tenían un contenido mítico para los habitantes de la colonia griega y por ello son escogidas y fijadas para siempre como emblemas de la ciudad.

Otro foco inicial de la amonedación hispánica, ahora trasladándonos al mediodía peninsular, es Gadir que comienza sus emisiones ${ }^{2}$ en el inicio del siglo III a.C. (Alfaro, 1988). Es de todos sabido que esta ciudad es una de las más tempranas en adoptar una iconografía griega, un Heracles para efigiar su divinidad fenicia, en los anversos (Fig.2.1). En efecto, la representación de la divinidad fenicia con leonté e imberbe reproduce aquí una de las facetas de la variada naturaleza del dios, aquella que lo aproxima al Heracles griego que populariza y enriquece en contenido la amonedación alejandrina, y que también ha dejado huella en aspectos relacionados con el culto y determinados elementos escultóricos o de otro tipo a los que se refieren las fuentes. Una relación, no sólo iconográfica, que a pesar de sus antiguos precedentes orientales adquiere un particular desarrollo cuando, ya desde el siglo VI a.C., al menos, la región del Estrecho había pasado a formar parte del espacio mítico griego del extremo Occidente; si bien habrá que esperar a la época helenística y romana para asumir una mayor helenización de los cultos gaditanos que, no obstante, debieron mantener durante mucho tiempo su esencia oriental. En cuanto a los reversos, éstos generalizan una imagen propia y personal, los atunes $\left(C N H, 83, \mathrm{n}^{\circ} 8\right)$, que han tenido diversas interpretaciones, pero antes de analizar las razones que llevaron a la elección de estos tipos resulta interesante señalar, por las implicaciones religiosas, económicas y políticas que conlleva esta elección, que estas imágenes se alejan de la tipología tradicional cartaginesa.

\footnotetext{
2 Vamos a dejar a un lado las interesantes piezas dadas a conocer recientemente por García-Bellido (2002a: 104-
}

Conviene recordar en este sentido que esta misma independencia o alejamiento se refleja en el sistema metrológico usado por Gadir, aunque no vamos a entrar en detalles pues se apartaría de la temática de este Seminario, decir que estas monedas tienen su mejor paralelo en las primeras dracmas ampuritanas y fueron acuñadas, como ha analizado García-Bellido (2000, 127-144; García-Bellido y Blázquez, 2001, 83-87), siguiendo un patrón monetal independiente del de Cartago y que se vincula con un antiguo patrón ponderal fenicio-tartésico documentado gracias a un juego de ponderales del siglo $\mathrm{V}$ a.C. encontrado en Cancho Roano (Zalamea de la Serena, Badajoz), que testimonia la existencia de un metrología siria (García-Bellido, 2002b: 127-155). Según la citada autora, la primera moneda de Gadir, habría venido simplemente a acuñar el valor de cuenta del dinero premonetal, nacido del sistema metrológico usado en la región desde quizás los siglos VII-VI a.C. Estos datos, en otro orden de cosas, podrían también avalar la hipótesis de aquellos investigadores que consideran que no fue necesaria la intervención de Cartago para canalizar la distribucción de los productos pesqueros gaditanos y proponen que ésta se organizaba desde la misma ciudad, hipótesis que encuentra refrendo en la ausencia de numerario cartaginés y la exlusividad de numerario de Gadir constatado en las factorías de salazón y en los alfares destinados a elaborar los contenedores de estos productos (Arévalo, 2004). Un tipo de circulación monetaria que quizás nos esté dando una valiosa información sobre en manos de quién está el control de estas actividades. Lo que al mismo tiempo puede conducir a ver a Gadir como polis aliada y no como súbdita de Cartago, en la línea defendida por Arteaga (1994: 25-58).

La elección de los tipos gaditanos se explica por parte de unos autores por la combinación del importante culto a Melkart, centrado en el más antiguo y prestigioso santuario del dios en Occidente, y la principal fuente de riqueza de la ciudad, basada en la fabricación y comercialización de las salsas y salazones de pescado. Mientras que otros autores consideran que los atunes han sido elegidos por estar asociados a la divinidad, por ser el producto procurado por Melkart, el dios del comercio, en cuyo santuario los comerciantes consagraban a la divinidad una victima para propiciar los beneficios que se espera recibir como frutos del mar. No conviene olvidar que los fenicios admitieron al pez como ofrenda votiva, pero

106) por la inseguridad de su atribución. 
sabemos que mientras ciertas especies estaban prohibidas, el atún era unos de los peces religiosamente lícitos; este uso pasó a Cartago y a las colonias occidentales, como muestra la representación de peces en ofrendas figurativas (Fernández Nieto, 2002: 253). Es esta idea, del atún asociado a la divinidad, como producto procurado por Melkart, la que creemos que ha sido la razón de la elección, sí se acepta la hipótesis de una vinculación entre esta divinidad y las atalayas atuneras, es decir que los thynoskopeia estuvieran puestos bajo la protección de Melkart. Así, y como ha expuesto Fernández Nieto al referirse a Hemoroskopeion "su doble condición de observatorio y de lugar consagrado puede ser consecuencia de que la tarea del vigía no está lejos de representar un ritual secreto y religioso, y de que es capaz de interpretar como un profeta o adivino las señales que desde el mar remite la divinidad en forma de banco de atunes". De esta forma, el buscado nexo de unión en la imagen que se intentaba transmitir a través de las dos caras de la moneda resultaba plenamente conseguido.

Por otra parte, se ha puesto en relación esta iconografía con la posibilidad de que radicase en el templo dedicado a Melkart el inicio de las acuñaciones de Gadir (Chaves y García Vargas, 1991: 158-160; Alfaro, 1993: 27-28), e incluso se ha llegado a plantear que estas emisiones pudieran ser la colaboración financiera del santuario a la red comercial de la que formaba parte y a la que protegía. Hipótesis que, aunque en un principio fue planteada fundamentalmente en base a la iconografía y a la ausencia del nombre del emisor de estos primeros bronces (Manfredi, 1985: 3-8; 1987-88: 81-87; 1987: 67-88), se ha querido reforzar a través de los hallazgos de estas primeras monedas en la factoría de salazones de Las Redes (Puerto de Santa María, Cádiz) y los documentados en ambientes industriales relacionados con estas actividades (Chaves Tristán, 2000: 117-126), como son los alfares de Torre Alta (San Fernando, Cádiz).

No obstante, creemos que no se puede olvidar que después de estas primeras monedas, Gadir siempre hizo constar no sólo el topónimo sino también una fórmula administrativa $p$ ' $l t$ interpretada como "acuñación u obra de Gadir" $\left(C N H, 82, \mathrm{n}^{\circ} 1\right)$. Esta novedad epigráfica podría tratarse, como han señalado García-Bellido y Blázquez (2001: 146), de una constatación de que las monedas son acuñaciones de la ciudad y no del santuario; sin duda esta leyenda monetal invita a reflexionar acerca de las razones que motivaron su inclusión y, creemos también que por extensión, de la función que tuvieron en origen una y otra emisión (Fig.2.3). Al hablar de esta primera serie de Gadir, García-Bellido y Blázquez (2001: vol. I. 24 y vol. II, 146) se refieren a ella como "óbolos votivos" para el santuario, pero al mismo tiempo reconocen desconocer su función, sin duda por la falta de testimonios arqueológicos. Sin embargo, muy recientemente hemos tenido ocasión de estudiar un hallazgo de dos de estos pequeños bronces anepígrafos formando parte de un acto de abandono ritualizado (Arévalo, 2004), hallazgo que, como a continuación veremos, puede ser testimonio de que estos bronces fueron realizados por y para el templo; aunque en un momento posterior a su fabricación pasaron a circular con valor monetal y se vincularon a la actividad económica de la ciudad, que giraba en torno a la producción de conservas marinas y de los contenedores destinados a exportarla, de ahí que las encontremos en Las Redes y en Torre Alta.

El citado hallazgo monetal se documentó durante las últimas intervenciones arqueológicas acometidas en el año 2003 en el conocido yacimiento alfarero de Torre Alta (San Fernando, Cádiz). En efecto en los niveles de colmatación del horno $n^{\circ} 4$ se halló (Sáez, 2004), casi sobre el suelo de la estructura fornacea, además de las dos monedas de la primera serie de Gadir-una mitad (Fig. 2.1) y un cuarto (Fig. 2.2)-, varias ollas, urnas, un ánfora grecoitálica de imitación de reducidas dimensiones, una pequeña jarra dentro de un vaso de perfil en $\mathrm{S}$, protegido con el cuello de un ánfora del tipo T.8.2.1.1.; todos estos recipientes aparecieron prácticamente completos y depositados junto a la pared Este y la columna de la estructura fornacea, con una disposición claramente intencionada. Este tipo de abandono, según sus excavadores, denota una planificación a la hora de su sustitución, mediante la realización de un acto de abandono ritualizado, y no una ruina súbita, que ellos sitúan en los primeros años de la presencia bárcida, entre el 240-230 a.C. En este hallazgo monetal creemos que podemos tener un recuerdo de la función votiva que en origen tuvieron estos bronces. Y hablamos de recuerdo, porque pensamos que en el momento en que se hizo este abandono ritualizado, el numerario de Gadir podría estar ya vinculado, como comentábamos antes, a la actividad económica de la ciudad. Pero este numerario sería ya las monedas con la leyenda "acuñación u obra de Gadir", constatando que a partir de ahora son acuñaciones de la ciudad, no del santuario, y que fueron fabricadas para realizar ciertos pagos relacionados con la producción y el transporte de las mercancías de ahí que las encontremos en contextos industriales. Es posible que estas nuevas monedas tomaran como 
modelo iconográfico esos pequeños primeros bronces, por la facilidad de ser aceptada por los receptores, al ser una iconografía claramente conocida, y por el grado en que se adecuaba a la función para la que se había previsto. Esos antiguos bronces pudieron seguir usándose, pero ya con una función claramente distinta para los que fueron fabricados y, de ahí que los encontremos en factorías de salazones y alfares.

Recientemente, García Vargas y Ferrer Albelda (2001: 33) han insistido en el hecho de que "cabe insertar la emergencia de la industria de conservas marinas en un amplio proceso histórico que converge en la constitución de auténticas polis occidentales cuyo rasgo más relevante es la transformación o la sustitución de las élites coloniales por una oligarquía ciudadana de nuevo cuño bajo cuyo control, ..., se hallaría el proceso económico de las salazones". Así mismo, García Vargas (2000: 39) ha argumentado que es probable que "como consecuencia de la constitución de las entidades ciudadanas, los símbolos religiosos, asociados a la aristocracia relacionada con la casa real tiria, que era la que surtía de personal rector a los diferentes templos, hayan sido asumidos por las nuevas oligarquías como signos de identidad política capaz de atraer hacia sí las voluntades de la comunidad ciudadana, pues no ha de olvidarse que el proceso de "desacralización" que preside la conformación de éstas ha de llevar aparejada una labor "ideológica" que aísle, asuma y legitime los símbolos religiosos propios de la aristocracia "regia", lo que nos pone ante un proceso intuido de "democratización" y ampliación de la base social oligárquica...". Es en este momento de "desacralización" y en este proceso de cambio social en el que creemos que se insertan sin problemas estas monedas, en ellas queda reflejada la aceptación de esos antiguos símbolos religiosos, quizás ya como signos de identidad política, pero también la plasmación de esta oligarquía ciudadana a través de la leyenda monetal.

Con la iconografía de Gadir hemos comprendido que cuando se eligió esa imagen de Heracles para el anverso se efectuó una interpretatio Graeca de Melkart, y para el reverso se fija ya de modo emblemático, el atún; pero al mismo tiempo estas imágenes evidencian una estrecha relación con los poderes fácticos: religioso y político, son pues estas imágenes monetales claros ejemplos de emblemas político-religiosos.

\section{LAS IMÁGENES MONETALES DE LA Hispania Republicana}

Analizados dos de los precedentes monetales veamos a continuación las imágenes que proyecta la Península Ibérica, una vez que fermenta en los distintos pueblos y culturas el fenómeno monetario, hecho que como se sabe tendrá lugar a partir de la Segunda Guerra Púnica.

Tan sólo una rápida ojeada sobre la tipología de las cecas de la Citerior y las de la Ulterior marca dos mundos diferentes en cuanto a la selección de tipos se refiere. La Citerior tendrá toda ella una homogeneidad tipológica, con variantes en los símbolos monetales; mientras que en la Ulterior existe una fuerte tendencia a la personalización de los tipos de manera que las individualidades ciudadanas queden bien marcadas, acompañándolas también del tópico ciudadano. La diferenciación de cada ciudad a través de los tipos monetales refleja una clara conciencia de diversidad tanto entre ellas como respecto a la Citerior.

\section{LAS IMÁGENES de LA CiTERIOR}

La monotonía iconográfica de la Citerior encuentra un llamativo aunque parcial contraste en la región costera levantina. Aquí, junto a la huella que también dejará la tipología del jinete ibérico, la diferente realidad social, política y cultural con una notoria tradición urbana podría ayudar a explicar el talante iconográfico diferente que aquí ofrecen algunas de sus amonedaciones, como es el caso de Arse (Ripollès y Llorens, 2002: 63-120), la primera ciudad ibérica en acuñar moneda.

Salvo estas excepciones de la costa levantina, los tipos del denario y de las unidades de bronce de la Citerior son una cabeza masculina en anverso con diferentes símbolos en campo, y en reverso un jinete lancero, o con palma, o diferente armamento. Para las mitades, la misma cabeza en anverso y un caballo suelto en reverso. Para los divisores más pequeños un prótomo de pegaso o hipocampo.

El análisis de tales tipos plantea numerosas dudas (Almagro, 1995: 53-64; Arévalo, 2003: 6374), pero lo que nos interesa ahora es resaltar que antes de que se emitieran estas monedas, los íberos habían copiado la moneda de más prestigio de la zona, nos referimos a las dracmas ibéricas de imitación ampuritana, sin importarles el hecho de que la iconografía se escapase de su comprensión o, aunque fuese comprendida se entendía que pertenecía a otra sociedad y no a la propia. Hasta ese momento parece que no interesaba integrar en la sociedad la ideología que expresa los tipos iconográficos de la moneda emporitana; sin embargo, sí interesaba integrar la moneda físicamente pues implicaba integrarse en los circuitos comerciales de la potencia económica predominante. La copia de la tipología y de la metrología de la moneda económicamente más fuerte no implica el dominio político de las zonas que copian, sino la adaptación de éstas, por propia iniciativa, a las redes comer- 


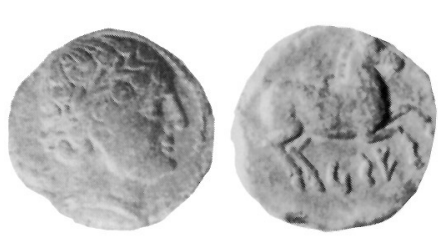

1
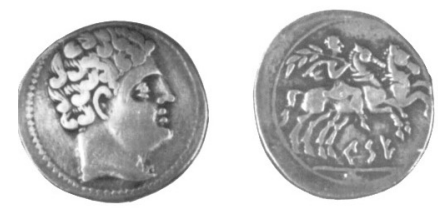

4
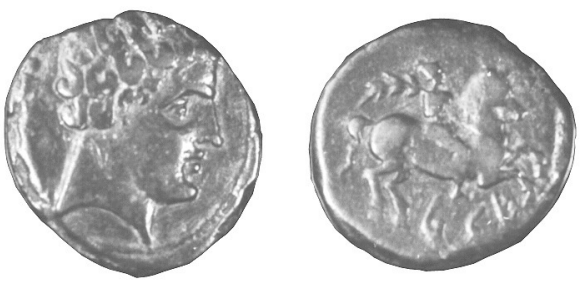

2
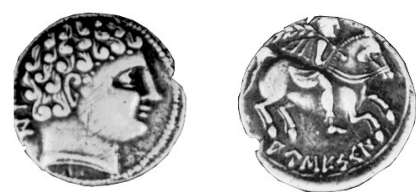

5
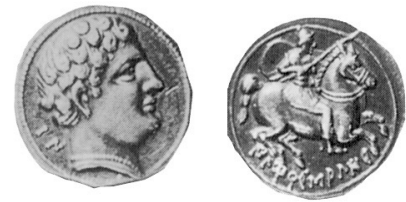

3
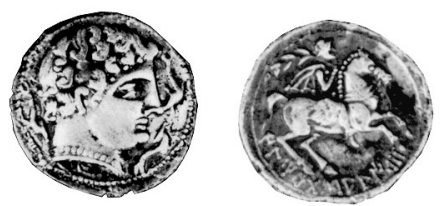

6
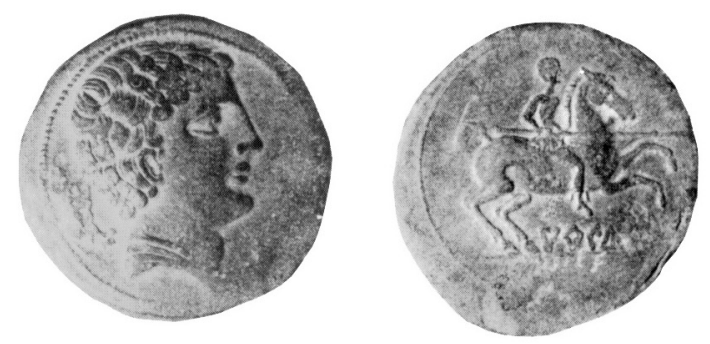

7

Fig. 3: 1. Mitad de Kese (CNH, 158, $\mathrm{n}^{\mathrm{O}}$ 1); 2. Unidad de Kese (MAN); 3. Dracma de Iltiŕké́alir $\left(C N H, 36, \mathrm{n}^{\circ} 1\right) ; 4$. Denario de Kese (MAN); 5. Denario de Auśesken (MAN); 6. Denario de Iltirta; 7. As de Aŕketuŕki (CNH, 182, no 1)

ciales mediterráneas más dinámicas.

El hecho de que se sustituya Emporion por Tarraco como base operativa de Roma en la Península Ibérica contra Cartago en la Segunda Guerra Púnica, habría potenciado la inclusión del sistema monetario de Kese en el circuito económico de Roma, convirtiéndose en la moneda a copiar en adelante, y es precisamente esta ceca la primera que utiliza el tipo del jinete, en este caso portando palma; previamente y, según Villaronga (1983) había emitido una primera serie con sólo un valor, una mitad con cabeza varonil imberbe en anverso, y un caballo al galope en el reverso $\left(C N H, 158, \mathrm{n}^{\circ}\right.$ 1), lo que demuestra una determinante influencia

\footnotetext{
3 Knapp (1977: 1-18) las fecha en el 195 a.C. y Crawford (1985: 95) un poco antes de la emisión del denario ibé-
}

del numerario hispano-cartaginés en el tipo elegido (Fig. 3.1). Será a partir de la segunda serie cuando en ciertos valores -unidad (Fig.3.2) y media y unidad- aparezca en el reverso el tipo del jinete, aunque con palma $\left(C N H, 159, \mathrm{n}^{\circ} 3,4\right)$. Todas son monedas de bronce con metrología púnica $\mathrm{y}$ leyenda ibérica, emitidas, según Villaronga (1983; 1984: 205-215; 1994: 158), ya antes del 211 a.C., durante la Segunda Guerra Púnica. Esta cronología ha sido aceptada por la mayoría de los investigadores; aunque hay autores que han retrasado las fechas ${ }^{3}$, situándolas hacia el 195 a.C., otros investigadores se inclinan por una fecha un poco anterior, así García-Bellido y Ripollès (1998: 208) consideran que su emisión es anterior al desembarco 
romano del 218 a.C. y vinculan estas piezas a los cartagineses $^{4}$.

En plata, el tipo del jinete lo encontramos, por vez primera, en unas interesantes piezas: una dracma con leyenda en reverso Iltiŕkésalir (Fig. 3.3) y en anverso ban (CNH, 36, $\left.\mathrm{n}^{\mathrm{o}} 1\right)$, y unos divisores con los signos ibéricos ban en anverso y reverso ( $C N H, 36-37, \mathrm{n}^{\circ} 2$ y 3). Monedas que, como han visto diversos investigadores (Villaronga, 1980: 43-56; 1998; García-Bellido, 1993b: 114; Pérez Almoguera, 1996: 42), fueron acuñadas, muy posiblemente, en la misma ceca que emitió los bronces ibéricos con leyenda Iltirkesken $(C N H, 200)$ a partir de la primera mitad del siglo II a.C. El modelo de jinete con lanza y escudo colgando a la espalda que vemos en estas piezas, fue puesto en relación por Villaronga (1980: 43-56) con las estateras tarentinas de fines del siglo III a.C. Y el nuevo estudio de conjunto de todas estas emisiones ibéricas (Villaronga, 1998), le ha llevado a defender la coetaneidad de las dracmas con leyenda Iltirkésalir con las primeras emisiones de dracmas ibéricas; así como a defender la fecha del 218 a.C. para el inicio de las dracmas ibéricas. Sin embargo, García-Bellido (1993b: 114) ha opinado que estas piezas unen las dracmas ibéricas de imitación y el denario ibérico, fechándolas entre los años 195-180 a.C., al considerar que el estilo y la factura de la cabeza masculina del anverso y la disposición de ataque del jinete del reverso en las dracmas de Iltiŕreśalir es idéntico a los denarios ibéricos más antiguos, que son los acuñados en Kese (CNH, 160, n $\left.{ }^{\circ} 17-19\right)$, Auśesken (CNH, 185, $\left.\mathrm{n}^{\mathrm{o}} 4\right)$ e Iltiŕta $\left(C N H, 176, \mathrm{n}^{\mathrm{o}} 4-5\right)$; así como por presentar la misma marca - ban- que los últimos denarios citados (Fig.3.4,5 y 6).

Hay, no obstante, que hacer una serie de matizaciones respecto a los tipos de estos primeros denarios; pues, aunque en todos se observa una disposición parecida en el jinete, las piezas de Kese, Auśesken e Iltiŕta llevan un jinete con palma, además de estar en Kese acompañado de un segundo caballo, abandonando la tradición de los bronces emitidos en las últimas décadas del siglo III a.C., en los que tan sólo figura un jinete; mientras que en las monedas de Iltirkeśalir aparece el jinete sólo y portando lanza, en una actitud algo más clara de ataque que en estos primeros denarios. Será en los bronces de Aŕketuŕki (CNH, 182, $\left.\mathrm{n}^{\mathrm{O}} 1\right)$, Ilturo (CNH, 193, $\left.\mathrm{n}^{\mathrm{o}} 1\right)$ y Kelse

\footnotetext{
4 Estas primeras emisiones de Kese vinculadas a los cartagineses podría encontrar un refrendo arqueológico con los datos aportados por Bendala y Blánquez refe-
}

(CNH, 222, $\left.\mathrm{n}^{\mathrm{O}} 1-2\right)$, ya de la primera mitad del siglo II a.C., donde de nuevo encontremos un jinete con lanza, aunque ahora en ristre (Fig.3.7).

Hay que tener por tanto en cuenta que las primeras monedas ibéricas, como comentábamos supra, no son las que presentan jinete con lanza, sino las del jinete con palma emitidas por Kese, antes del 211 a.C., según Villaronga, o quizás hacia el 218 a.C., como proponen García-Bellido y Ripollès. Por tanto, estas piezas nos proporcionan valiosos indicios para conocer el origen de la tipología del jinete en la moneda ibérica. Es evidente, como veíamos antes, que la metrología no responde a un patrón romano, y tampoco lo es la tipología, pues hasta el 212-209 a.C. no se crea el denario, con los dióscuros como tipo característico en reverso. Por otra parte, no parece del todo adecuado considerar las acuñaciones de Hierón II como el modelo más inmediato para estas primeras acuñaciones de Kese con jinete portando palma, pues aquel acuñó moneda con jinete con lanza. De ahí que Villaronga (1983) calificara el tipo del jinete con palma como una innovación autóctona, que evidentemente debió tener un peso simbólico específico en la sociedad en que se crea.

Las últimas hipótesis sobre el modelo del jinete ibérico han sido las de García-Bellido (1992: 246; 1993b: 101), quien admite la posibilidad que el modelo procediera, en última instancia, de los bronces de Hierón II y propone que las monedas de Kese acuñadas durante la Segunda Guerra Púnica, en cuyas emisiones están fijados los tipos para los diferentes valores, serían el prototipo más inmediato del jinete ibérico. Mientras que Almagro (1995: 58) opina, al igual que los anteriores autores, que los primeros jinetes aparecen en Kese, siendo una innovación frente a la tradición púnica seguida en sus monedas con caballo a derecha y la metrología púnica de estas primeras acuñaciones. Y que el modelo originario fueron los jinetes macedónicos repetidamente ilustrados en la moneda helenística como símbolo del héroe ecuestre; idea que en los últimos trabajos García-Bellido (1999: 211) parece también aceptar.

Después de todo lo expuesto creemos que la iconografía del jinete ibérico surge de forma autónoma en la ciudad de Kese, pero trasladando al ámbito propio ideas que circulan por todo el ámbito mediterráneo. No debemos olvidar,

ridos a la arquitectura militar púnico-helenística constatada en Tarragona, publicados en este mismo volumen. 
como muy bien ha analizado Almagro, que el tipo del jinete portando palma aparece antes utilizado con profusión por la dinastía Macedonia, especialmente en piezas acuñadas por Filipo de Macedonia, de donde pasará el tipo a Tarento y Bruttium, y que aparecerá después en el tipo de los Dióscuros. En consecuencia, estamos ante tipos iconográficos sobradamente conocidos en todo el ámbito Mediterráneo, un mundo muy dinámico donde las ideas tardan relativamente poco tiempo en llegar desde las áreas más desarrolladas del Próximo Oriente y del Egeo hasta Occidente. Estos tipos iconográficos creados en las áreas culturalmente más dinámicas serían readaptados por otras sociedades, como por ejemplo la ibérica, que las incorporan a su propio sistema socio-ideológico y los dotan de un significado pleno y comprensible.

En cuanto a la adopción de este tipo en toda la Citerior, como comentábamos supra, el hecho de que se sustituya Emporion por Tarraco como base operativa de Roma en la Península Ibérica contra Cartago en la Segunda Guerra Púnica, habría potenciado la inclusión del sistema monetario de Kese en el circuito económico de Roma, convirtiéndose en la moneda a copiar en adelante. Es decir, se empezaría copiando esta iconografía porque, desde las acuñaciones autóctonas de Kese, es la moneda de mayor prestigio que permite incorporar las emisiones de los oppida que sucesivamente acuñan moneda dentro de un complejo económico mucho más vasto, al que se accede a partir de la intervención romana en la Península. Pero, también, habría sido copiado el tipo porque resultaría bien conocido, fácilmente asimilable y con unas connotaciones que se adaptan a las características socio-ideológicas de los oppida ibéricos. Parece que la idea de estas cecas es la de resaltar su pertenencia a una amplia comunidad, pero marcando al mismo tiempo su individualidad, de ahí los diversos símbolos. Lo que no cabe duda es que esta imagen acaba convirtiéndose en emblema de toda la provincia Citerior, las largas rebeliones contra Roma, en la que muchas veces estos distintos pueblos se unieron para defenderse, la unidad de escritura y de imagen monetal acabó por convertirse en un claro reflejo de identidad colectiva.

En cuanto al significado de esta imagen monetal, la propuesta que hizo al respecto Almagro (1995: 240) ha sido hasta el momento bastante aceptada. Estaríamos en el caso de la cabeza varonil, ante la representación de una divinidad local, posiblemente con carácter etnopoliádico de la ciudad o pueblo que acuña y que pone su nombre en la moneda, identificada con la autoridad local de origen divino, y en cuanto al jinete del reverso queda identificado con la figura del heros equitans, correspondiendo ambos tipos al universo ideológico de unas élites ecuestres, que serían las mismas en usar, como símbolos de estatus, atributos materiales externos tales como joyas, fíbulas; de ahí que las cabezas masculinas de los anversos lleven según los pueblos estos distintos símbolos. Sin duda estos elementos simbólicos y materiales definidores de una superioridad social están en relación con los grupos dirigentes de las comunidades hispanas, grupos oligárquicos que dominaron con relativa independencia los asuntos públicos locales.

\section{LAS IMÁGENES DE LA ULTERIOR}

En claro contraste con lo anteriormente expuesto se nos muestra el panorama iconográfico de la Ulterior, en cuyas monedas existe una fuerte tendencia a la personalización de los tipos de manera que las individualidades ciudadanas queden bien marcadas, acompañándolas también del tópico ciudadano. La diferenciación de cada ciudad a través de los tipos monetales refleja una clara conciencia de diversidad tanto entre ellas como respecto a la Citerior. Tanto su sistema político de polis, como étnico al ser ellas cobijo de diferentes pueblos, ajenos en ocasiones al territorio peninsular, habían favorecido la independencia política y cultural de unas urbes frente a otras, siendo la variedad de la tipología monetal su mejor testimonio (Chaves, 2003: 1820).

El tema de la personalización de los tipos de la Ulterior, lo que al mismo tiempo no quita que se marquen también analogías con otras, se presta a un estudio profundo que evidentemente no podemos abordar aquí, sí diremos que la principal característica de la tipología de estas acuñaciones es la combinación de imágenes antropomorfas, zoomorfas o vegetales y símbolos astrales. Por otra parte estos tipos fueron efigiados con un lenguaje clásico, que unido al hecho de que una gran parte de las acuñaciones monetales de esta zona presentan epígrafes latinos, llevó a hablar de una fuerte romanización frente a otras áreas que acuñan conservando su alfabeto y sus tipos tradicionales. Sin embargo, la profundización en aspectos como la iconografía y la metrología de las emisiones apunta a que el sustrato púnico sigue siendo muy potente, al menos en las elites encargadas de la acuñación monetal.

Los recientes estudios arqueológicos tanto en la región de Cádiz como en el valle del Guadalquivir vienen aportando importantes datos sobre la presencia púnica (Bendala, 1994: 59-74; 2000: 75-88), que está permitiendo ir acep- 


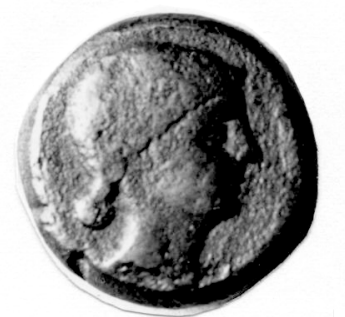

1
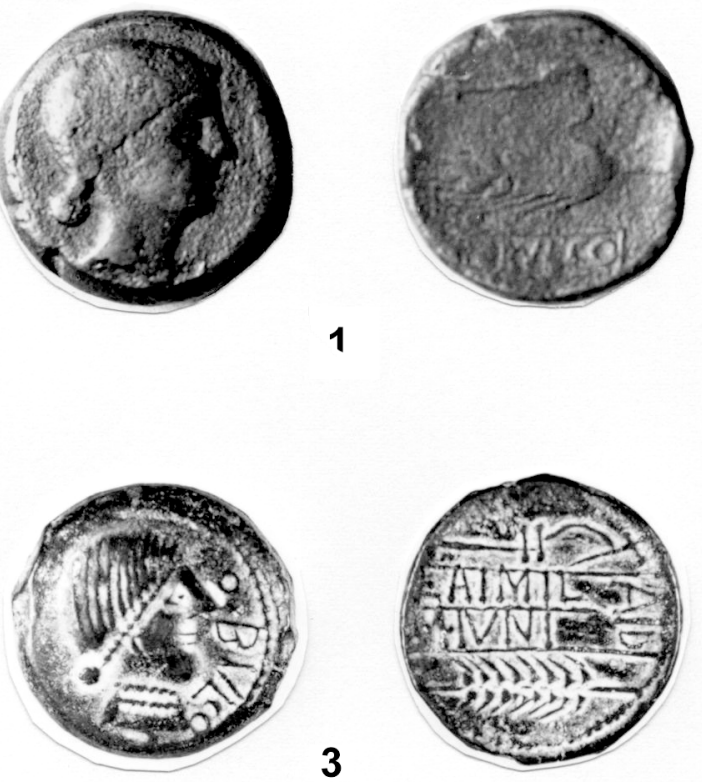

3

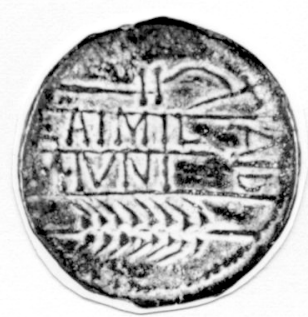

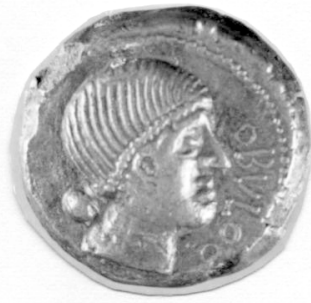

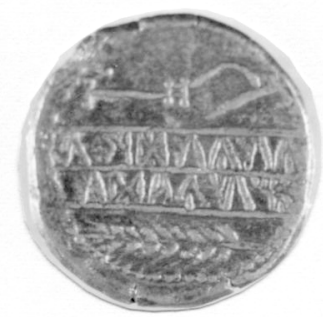

2
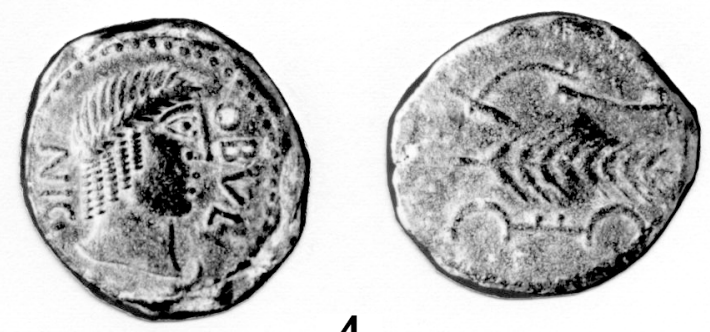

4

Fig. 4: 1. Duplo de Obulco (MAN); 2. Unidad de Obulco (MAN); 3. Unidad de Obulco (MAN); 4. Unidad de Obulco (Col. Particular)

tando la llegada de nuevos contingentes del mundo púnico norteafricano a partir del siglo IV a.C., sin duda ello reforzó los elementos fenicios en ciudades en las que este componente étnicocultural era mayoritario, pero también dejaron sentir su acción en el mundo turdetano circunvecino, en absoluto ajeno a este importante componente cultural como sabemos. Será sobre este importante trasfondo cultural sobre el que se desarrollará más tarde la nueva política que introducirán los Barca a partir del 237 a.C., materializado en la llegada de nuevos grupos humanos que participaran en las fundaciones coloniales promovidas por ellos o que serán asentados o establecidos en determinados lugares de lo que luego será la provincia Ulterior. A ello debemos sumar la llegada de tropas que participaron en las diferentes campañas que los cartagineses sostuvieron en Hispania antes de su derrota, tropas que como ha expuesto Domínguez Monedero (1987: 129138; 1995: 111- 116) debieron ser en algunos casos asentados en la península, según se deduce de un pasaje de Apiano (Iber., 56) referido a la sublevación del cabecilla lusitano Púnico. Sin querer entrar de lleno en las implicaciones que éstos y otros datos arqueológicos y textuales tienen para ir conociendo el peso del componente étnico-cultural vinculado al mundo púnico norteafricano en la conformación de la realidad indígena del sur peninsular, lo que si parece es que este trasfondo es cada vez más seguro.

Si pasamos de nuevo al terreno de la iconografía monetal del sur peninsular, este componente parece también obvio, no sólo en aquellas cecas claramente fenicio-púnicas, o en las denominadas libiofencias, o en las que aún situadas en el interior utilizan rótulos púnicos, sino también en aquellas que a través de la iconografía se hacen eco de una adopción pública de una identidad cívica púnica. En efecto, nos referimos a aquellas acuñaciones del área del Alto, Medio y Bajo Guadalquivir, así como de la serranía gaditana, que aunque utilizan en sus leyendas el alfabeto latino, emplean una iconografía helenística llegada a través de las colonias fenicio-púnicas o una iconografía claramente vinculada con el mundo púnico norteafricano, y de ahí que muestren esquemas compositivos y tipos semejantes a aquellas cecas con rótulos púnicos, neopúnicos o los denominados libiofenicios.

Vamos a utilizar como ejemplo de lo dicho la ceca de Obulco, en la alta Andalucía, y la de Carisa, en la serranía gaditana, pero los datos extraídos del estudio de sus amonedaciones pueden extrapolarse a otros talleres béticos.

Obulco (Porcuna, Jaén), ciudad bien conocida literaria y arqueológicamente, y de la que realizamos un análisis interno de sus emisiones (Arévalo 1999), tiene como característica constante de en sus unidades (CNH, 341-347), salvo 

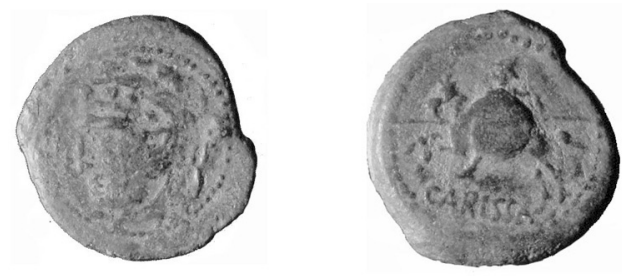

1
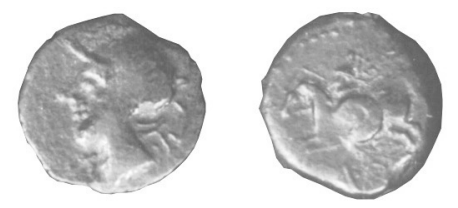

3
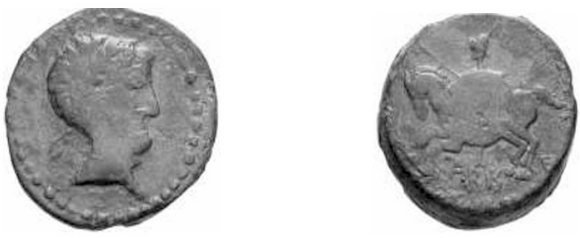

2
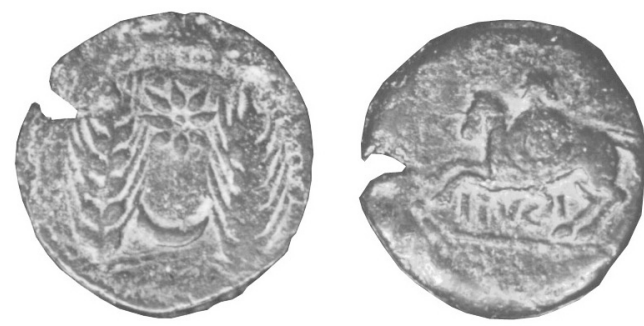

4

Fig. 5: 1. Mitad de Carisa (Subastas Cayón 2000); 2. Mitad de Carisa (Col. Particular); 3. Mitad de Carisa (MAN); 4. Divisor de Ituci (MAN)

en la última emisión (Fig. 4.4), el efigiar en su anverso una cabeza femenina con un peinado muy característico - una trenza rodea la cabeza para terminar en un moño a la altura de la nuca-; en ocasiones se rodea de una corona de pequeñas hojas, y a veces le acompaña un creciente (Fig. 4). La personalidad estilística de los anversos se refuerza con la singularidad del tipo de los reversos que ayuda a caracterizar el contenido principal de la divinidad, la espiga, tan repetida en todo el Mediterráneo, cobra un sabor especial al combinarla en original composición con arado e incluso en algunas emisiones con un yugo. Es por tanto una divinidad astral, frugífera y protectora de los trabajos agrícolas, sin duda una divinidad acorde por otra parte con la realidad económica de la ciudad, se trata de un importante centro de explotación y redistribución agraria, como han puesto de manifiesto los enormes silos excavados.

En la efigie del anverso se ha querido ver la representación de diferentes divinidades; sin embargo, como ya defendimos en el estudio monográfico que realizamos de esta ceca, no hay duda que para estas unidades se elige la imagen de una divinidad femenina fructífera y astral, descrita con un lenguaje similar al que Tanit muestra en las estelas africanas de los siglos III-I a. C. ${ }^{5}$, como la estela del santuario de El-Hofra en Constantina (Berthier y Charlier, 1955, 193, lám. XXX, d) donde figura un yugo, similar al de estas acuñaciones, debajo el "signo de Tanit" y a la derecha un caduceo. En otras ocasiones, el arado se encuentra acompañado del símbolo de la mano (Hours-Median, 1951, 66, lám. XXXVII,f).

El criterio selectivo de la tipología de esta ceca se mueve entre un particularismo indígena que propugna tipos cívicos que abarcan a la vez el matiz religioso y el económico, y una iconografía de raigambre púnica. Pero Obulco mantuvo paralelamente una tipología monetal autóctona con un uso del alfabeto latino desde el comienzo, hacia finales del siglo III a.C., aunque enseguida

\footnotetext{
5 Chaves Tristán y Marín Ceballos (1979: 669-670) consideran que debe tratarse de una diosa local con un culto principal en la Alta Andalucía extendido por la cabecera y el valle medio del Guadalquivir, debido a que esta imagen la encontramos parcial o fielmente repetida en las cecas de Abra, Ulia y Carbula. Y confieren a esta divinidad el carácter lunar y de fertilidad por apa-
}

recer en las monedas el creciente y la espiga, acepciones quizás asimilables a divinidades foráneas, bien del mundo púnico, Tanit, o griego, Artemis; aunque también opinan que ni los que seleccionaron el tipo ni la mayoría de los usuarios veían más que la divinidad adorada desde la cabecera del Betis. 
encontraremos una tendencia a la inclusión del alfabeto ibérico, primero en el propio topónimo de forma bilingüe, luego en los nombres indígenas de magistrados (Fig.4.2), para terminar con nombres de magistrados latinos que son llamados aediles, en pleno siglo II a.C. (Fig.4.3). Es difícil pensar que en una ciudad estipendiaria como era Obulco existiera en fecha tan temprana tal magistratura, más bien debemos ver, como han indicado Rodríguez Neila (1995: 261-274; 2000, 149-181) y García-Bellido junto a Blázquez (1995: 381-387; 2001: 49), una latinización del título indígena que poco tiene que ver con la administración romana. Como ha estudiado Rodríguez Neila existían muchas comunidades prerromanas de Hipania que contaban con unas bases institucionales antes de la llegada de los romanos, y pudieron ser utilizadas por el gobierno de la República para sus propósitos de descentralización administrativa. Por su parte, las élites locales, interesadas en ofrecer al dominador la mejor imagen de una positiva predisposición a colaborar, podían reforzar su "facies" romana, tanto en titulaciones y competencias, como en procedimientos, utilizando en este caso el alfabeto latino. Al mismo tiempo, no es sólo el componente local el único interesado en la puesta en marcha de las amonedaciones, aunque quizás los intereses por parte de Roma debieron tener sólo una vertiente práctica, disponer de monedas asequibles en la zona; lo que no cabe duda es que el control de las emisiones estaba en manos de las élites locales, que a la manera helenística colocan su propio nombre y eligen como emblema una divinidad femenina agraria y astral.

La otra ceca objeto de análisis es la de Carisa, localizada en el cortijo de Carija (entre Bornos y Espera, Cádiz), que al ser menos conocida que la anterior la dedicaremos aquí una mayor atención. Esta ciudad está enclavada en las estribaciones de la sierra de Gamaza y sierra del Calvario, en un área de cerros o colinas. Precisamente la ocupación de altas colinas le confiere unas características geoestratégicas de vital importancia para el establecimiento de población ya que domina el curso medio del valle del Guadalete, además de las fértiles tierras que riega éste, y el acceso que conecta con las sierras Sudbéticas. En ella destacan tanto la mag-

\footnotetext{
6 Es de destacar la existencia de hipogeos en la necrópolis sur, a modo de grandes mausoleos familiares excavados en la misma arenisca, con una clara huella púnica y una datación del siglo I a.C. (Perdigones Moreno, Molina Carrión y Rojo Corrales, 1987: 67-74; Lavado Florido, Perdigones Moreno, Aguilera Rodríguez y
}

nitud de los vestigios arqueológicos que aún afloran en el lugar, fundamentalmente funerarios ${ }^{6}$, como las interesantes acuñaciones que la ciudad emitió en un momento, aún impreciso, del siglo I a.C.

El estudio monográfico que estamos realizando sobre esta ceca, nos está permitiendo conocer la organización de su producción y las características de su fabricación; así hemos comprobado que es una ceca que recurre frecuentemente a la reacuñación, salvo en una emisión que nosotros hemos considerado la primera $\left(C N H, 409, \mathrm{~N}^{\circ} 6\right)^{7}$ por presentar una serie de características ausentes en el resto de las acuñaciones, tales como el topónimo escrito con dos $\mathrm{S}$, la combinación de una tipología diferente al resto de las series, cabeza de Hércules-Melkart para el anverso, y jinete con escudo redondo en el reverso (Fig.5.1), tipo constante en todas las emisiones al contrario que el del anverso, amén de la no recurrencia a la reacuñación (Arévalo, en prensa-a). Es precisamente en estas monedas, consideradas por nosotros como las primeras emitidas por el taller, donde se hace más palpable la procedencia de sus habitantes, pues se escoge una iconografía claramente parangonable con otras cecas púnicas. En efecto, para el anverso se selecciona una iconografía helenística llegada a través de Gadir y que encontramos en otras muchas cecas púnicas y con leyendas latinas, lo que no sabemos es sí el uso de esta tipología significa la expansión del culto a Melkart gaditano. Lo cierto es que, salvo el argumento numismático, contamos con escasos indicios de tal hecho (Oria Segura, 1996; 2002: 219-244), lo que ha llevado a algunos autores a buscar explicaciones alternativas. La más reciente para estas acuñaciones, propuesta por Chaves y García Vargas (1991: 139-168, 1994: 375-392), es de carácter económico, relacionada con el control gaditano de la industria pesquera y de los lugares que directa o indirectamente participan en la misma, sin excluir que la imagen resultara significativa para la minoría semítica que dirige el comercio. Por otra parte, Marín Ceballos (2002, 21-22) considera probable que el tipo numismático del Melkart gaditano constituyera, ya bajo la dominación romana, una especie de "marca" de identidad de una comunidad étnica, cultural y económica que, de este modo, tra-

Jiménez Pérez, 1990, 117-125; Lavado Florido y Perdigones Moreno,1990, 113-119).

7 Tanto Villaronga $\left(C N H, 409, \mathrm{n}^{\circ} 6\right)$ como García-Bellido y Blázquez (2001: 84, 3a emisión) sitúan esta serie entre las emisiones intermedias del taller. 
taba de resaltar su individualidad.

Personalmente pensamos que para el caso de Carisa, aunque como veremos hay otros elementos que han llevado a vincularla con la industria pesquera, la lectura étnico-cultural de su iconografía se hace más palpable en los reversos, que permanecen invariables a lo largo de toda la vida de la ceca, mientras que los anversos son cambiantes y además, salvo la excepción del tipo de Melkart de esta primera serie (Fig. 5.1), y la cabeza galeada (Fig.5.3) de otra emisión (CNH, 409, $\mathrm{n}^{\mathrm{o}} 3-5$ ), el tipo más habitual es una cabeza masculina tan pobremente descrita, sin iconografía propia, que necesita del reverso para caracterizar el contenido principal de la divinidad (Fig. 5.2): una divinidad de contenido guerrero. En efecto, el reverso utiliza una iconografía similar a la ceca púnica de Ituci (Campo de Tejada, Escacena, Huelva), donde se representa un jinete con el característico escudo $\left(C N H, 108, \mathrm{n}^{\circ} 1-4,108, \mathrm{n}^{\circ}\right.$ 7 y 109, no 8-9) (Fig. 5.4) que se ha vinculado con los jinetes númidas (Quesada y García-Bellido, 1995: 71), que entrarían como mercenarios durante la ocupación bárquida y que fueron pagados con tierras, permaneciendo en ellas tras la victoria romana.

En cuanto al patrón monetal usado, recordemos monedas de pequeño tamaño en bronce, se ha puesto en relación con el empleado en ambas orillas del Estrecho de Gibraltar (Chaves y García Vargas, 1991: 139-168), un patrón que además de estar relacionado con Gadir, se encuentra en función de una misma red de explotación comercial vinculada con la explotación de las salazones de pescado. De ahí que lo encontremos en cecas como Asido, Bailo, Lacipo, pero también al otro lado del Estrecho, como en Lixus, Tamuda, Tingi, etc.; monedas de pequeño módulo, que como han visto Chaves, García Vargas y Ferrer (1998: 1317), resultaban útiles para el uso que, en la zona del Estrecho y en el área de relaciones con ella, se les quería dar.

Por tanto, Carisa aunque hace uso de la escritura latina, su iconografía y su metrología permiten identificar esas emisiones, y con ello la ciudad, como de índole púnica, al mantener a través de las imágenes monetales sus emblemas étnicos; de esta forma sus monedas hacen alarde, como documento oficial emblemático, de la independencia cultural respecto a Roma. Al tiempo que evidencian la tolerancia de la administración romana con respecto a esta ciudad que había quedado integrada en su provincia, así como de la aceptación, por parte de esa misma administración, de la manifestación externa de la identidad cívica de esa ciudad.
La posible explicación para esta actuación por parte de la administración romana creemos que ha sido magníficamente tratada por Domínguez Monedero (2000: 59-74), al exponer que uno de los argumentos para determinar la afloración de esta identidad cultural se encuentra vinculado con los hechos acaecidos en el contexto bélico de las guerras lusitanas que afectaron a la Ulterior y que llevaron al propio Viriato a las proximidades de Gades, así y según el citado autor "no parece improbable que muchas de esas comunidades, cuyos círculos dirigentes se identificaban con esa cultura de impronta púnica, se mostrarán absolutamente leales a Roma; ello justificaría que los romanos autorizasen (o, al menos, no impidiesen) que pudieran expresar a las claras su vinculación a ese mundo semitizante"; por otra parte, la exhibición de los elementos más distintivos de su etnicidad fueron al mismo tiempo un medio de expresar su alejamiento de los sublevados. Junto a estos hechos Domínguez Monedero también valora otro elemento clave para el afloramiento de este panorama étnico-cultural, cuál es el surgimiento en estos mismos momentos de un poderoso estado númida en el norte de África, más o menos afín a Roma, que sin duda debió de influir sobre las poblaciones de ese origen que existían en Hispania que llevó a la revitalización de este componente étnico-cultural púnico.

Otro hecho que creemos que se debe destacar en la iconografía de Carisa, en relación a su similitud con la ceca de Ituci, es su posible ligazón con los beneficios de la comercialización del mineral. García-Bellido (2000, 136-144) ha defendido que en la acuñación bética hay que aceptar que fueron los púnicos quienes pusieron en marcha la monetización de la Turdetania, aunque ello fuera ya bajo auspicios romanos, y ello ocurre en las regiones donde se concentran ciudades púnicas de valor portuario o minero. Una de esas ciudades púnicas fue Ituci, donde la arqueología ha documentado sus explotaciones metalúrgicas, pero las monedas no hacen ninguna alusión emblemática a los trabajos mineros, por lo que la citada autora señala que el silencio iconográfico puede estar impidiendo la identificación de algunas otras ciudades involucradas en la minería. Acabamos de ver que Carisa es una ciudad que podría responder a los mismos orígenes militares que Ituci, de ahí su semejanza iconográfica, pero su emplazamiento no está vinculado con ninguna explotación minera, aunque si está próxima a explotaciones salineras, lo que ha llevado Chaves y García Vargas (1991: 139-168) a incluir esta ciudad dentro de la red económica controlada por Gades y vinculada con la explotación de 
las salazones de pescado; sin embargo creemos que también pudo estar ligada a otra red comercial, la de los metales.

En el estudio de las monedas Carisa hemos podido constatar un alto número de reacuñaciones sobre monedas de Castulo, cerca de 30 ejemplares, pero también sobre acuñaciones Obulco y Corduba, aunque en menor número. Por otra parte, en el estudio que acabamos de realizar sobre la circulación monetaria de esta zona de la serranía gaditana, a través de los fondos del Museo Municipal de Villamartín (Arévalo, Bernal y Gutiérrez, en prensa), hemos podido comprobar que el numerario más frecuente en esta área vuelve a ser el procedente de estas cecas, junto al de Carteia, que es el más numerosos. Un buen argumento para estos dos hechos, reacuñaciones y circulación monetaria, es postular una relación económica estrecha entre estas áreas en relación a la exportación de los metales de la alta Andalucía hacia la costa del Estrecho.

Recientemente, Melchor (1999: 314-322) ha defendido que el plomo y la plata producida en el distrito minero de Castulo saldría por la ruta Castulo-Malaca. Así mismo, considera que al puerto malacitano también pudo llegar el metal extraído en el distrito minero de Corduba, que sería transportado por otra vieja ruta ibérica acondicionada como calzada en época romana: la vía Corduba-Malaca. La confirmación del uso de estas rutas vendría dada por la circulación monetaria de Castulo, Obulco, Corduba y Malaca, cuyas monedas aparecen con cierta frecuencia en diversos puntos del recorrido de estas vías. Los transportistas necesitarían abundante numerario para pagar las pequeñas transacciones realizadas durante sus desplazamientos a Malaca, y junto a la moneda de plata llevarían bronces de estas cecas. Por tanto, el transporte del metal del alto Guadalquivir ayudaría a explicar la frecuencia de los hallazgos de monedas de Castulo, Obulco y Corduba en la zona costera malagueña o en el valle medio del Betis.

Esta propuesta nos parece del todo acertada, pero existen otra serie de evidencias numismáticas que permiten defender la posible existencia de otros itinerarios alternativos para exportar los metales de los distritos mineros cordubense y castulonense, como la ruta Corduba-Carteia, cuyo trazado describió Sillières (1990: 422-430), y que Mora (1999: 344-348) ha confirmado a través del análisis de la circulación monetaria en la ciudad de Acinipo (Ronda, Malaga), donde destaca la alta presencia tanto de numerario de Carteia como de Obulco, así como por las frecuentes reacuñaciones de Acinipo sobre moneda de Obulco. En este punto resulta particularmente interesante la propuesta defendida por Corzo y Toscano (1992: 150-154) sobre el diferente trazado para esta vía, lo que no impide aceptar la existencia de otras rutas que, como la propuesta por Sillières, comunicarían el Estrecho con el interior bético. Según Corzo y Toscanos, esta vía discurría por Astigi, Urso y Acinipo, y se internaba en las serranías gaditanas a la altura del actual pueblo de Puerto Serrano, descendiendo a Iptuci (Cabezo de Hortales, Prado del Rey, Cádiz) y la llanura de Hortales ${ }^{8}$. La identificación o no de esta ruta con la vía que refiere el Bellum Hispaniense no impide aceptar la existencia de rutas alternativas, de carácter secundario si se quiere comunicando la densa trama urbana de la Hispania meridional. La existencia de tal vía que pone en comunicación los asentamientos púnicos del Estrecho con la zonas mineras de Sierra Morena, parece confirmarse por la información que proporcionan tanto las reacunaciones de Carisa sobre moneda de Castulo, Obulco y Corduba, como por la circulación monetaria en la serranía gaditana, donde es frecuente este tipo de numerario junto con el de Carteia. Por otra parte, hay que indicar que en la ciudad de Carteia se han recogido en las distintas campañas de excavación realizadas durante los años 1971-75 piezas de Obulco, Carisa, Lascuta (Presedo et alii, 1982: 287-309) que vuelven a indicar, como venimos diciendo, una relación tanto con la serranía gaditana ${ }^{9}$ como con la alta Andalucía, a través de la vía que desde Corduba llevaba a Carteia.

La situación de la ciudad de Carisa, en las inmediaciones de esta vía, y su paralelo iconográfico con la ceca de Ituci pueden ser dos buenos argumentos para vincular esta ciudad con la

\footnotetext{
8 En este sentido, resulta interesante la noticia recogida por Corzo y Toscanos (1992: 150-154) al estudiar el recorrido de esta vía, donde señalan que "la única mención de un miliario que se conoce en la vía corresponde a este trayecto inmediato a Villamartín, donde se encontró uno a fines del pasado siglo, que se rompió al intentar trasladarlo a Arcos de la Frontera, sin que
} 
red de comercialización del mineral ${ }^{10}$. Por otra parte, recientemente García-Bellido (2001: 146) ha defendido que la presencia en la Beturia túrdula de cecas libiofenicias y de un circulante procedente de Asido, Vesci, Gades, Carteia y del Norte de África puede indicar que allí existían intensas relaciones económicas con los libiofenicios gaditanos. Considera que la Beturia túrdula pudo ser repoblada por las gentes del interior de Gades, quienes vieron en el rico mineral de esta zona (Estr., 3, 2, 3) un valor que podía comercializarse rentablemente, dándole salida a través primero de la vía terrestre que desde Metellinum por Artigi y Mellaria llevaba a Córdoba, donde un importante nudo de caminos les permitía, bien embarcar las mercancías por el Guadalquivir bien hacer uso de las otras vías terrestres que penetraban en Oretania para llegar a Castulo, la que descendía hasta Malaca y la que llegaba al puerto de Carteia (García-Bellido, 1995: 285).

Todos estos datos creemos que permiten defender que de nuevo, en el caso de Carisa, estamos ante una ciudad de raigambre púnica involucrada en la gestión de la exportación del mineral, aunque quizás también, como defienden Chaves y García Vargas, con la red controlada por Gades vinculada con la producción, comercialización y distribucción de productos relacionados con las conservas en sal. Más esencial, para lo que venimos tratando aquí, es que probable tengamos en las monedas de Carisa un nuevo testimonio de la procedencia númida y militar de sus habitantes, mercenarios que durante la ocupación bárquida son pagados con tierras $y$, tras la victoria romana, permanecen en la ciudad manteniendo sus emblemas étnicos pero introduciendo tempranamente, al igual que la mayor parte de las ciudades de la Ulterior, el latín.

\section{Bibliografía}

Alfaro Asins, C. (1988): Las monedas de Gadir/Gades, Madrid.

- (1993): "La ceca de Gadir y las acuñaciones hispanocartaginesas", Numismática hispano-púnica. Estado actual de la investigación. VII Jornadas de arqueología fenicio-púnica, Ibiza, 27-62.

Almagro, M. (1995): "Iconografía numismática hispánica: jinete y cabeza varonil”, García-Bellido, M ${ }^{\mathrm{a}} \mathrm{P}$. y Sobral Centeno, R.M. (eds.), La moneda hispánica. Ciudad y territorio, Anejos de Archivo Español de Arqueología XIV, 53-64

Arteaga, O. (1994): "La liga púnica gaditana. Aproximación a una visión histórica occidental, para su contrastación con el desarrollo de la hegemonía cartaginesa en el mundo mediterráneo", VIII Jornadas de Arqueología Fenicio-Púnica, Ibiza, 25-58.

Arévalo GonZÁlez, A. (1999): La ciudad de Obulco: sus emisiones monetarias, Sigüenza (Guadalajara).

- (2003): "La moneda hispánica del jinete ibérico. Estado de la cuestión", Quesada, F. y Zamora, M. (eds.), El caballo en la antigua Iberia. Estudios sobre los équidos en la Edad del Hierro, Madrid, 63-74.

- (2004): "Sobre la presencia de moneda en los talleres alfareros de San Fernando (Cádiz)", Actas del Congreso Internacional Figlinae Baeticae, B.A.R. int. ser., Oxford.

- (en prensa-a): "Variaciones e incorrecciones en las leyendas de las monedas de Carisa", III Encuentro Peninsular de Numismática Antigua (Osuna, 2003).

- (en prensa-b): “Aportación a la circulación monetaria de la Bahía de Cádiz: los hallazgos monetarios de la Avda. Pery Junquera (San Fernando, Cádiz)", XIII Congreso Internacional de Numismática (Madrid, septiembre de 2003).

Arévalo González, A.; Bernal Casasola, D. y Gutiérrez López, J.M. (en prensa): Romanos y Visigodos en Villamartín (Cádiz), Cádiz.

rosas ocultaciones existentes en el sur peninsular, con las minas, según la propuesta que venimos realizando. Así, y como opina Chaves al referise a los tesoros del sur peninsular, la gran eclosión de itálicos para explotar las minas en los últimos decenios del siglo II a.C. debió suponer un cambio en el papel que hasta entonces había mantenido la población indígena en la explotación y comercialización, y relaciona esta desestabilización con importantes movimientos de tropas, con destrucciones en zonas mineras y con este tipo de tesoros ocultados por problemas sociales. 
BEndala, M. (1994): "El influjo cartaginés en el interior de Andalucía", Cartago, Gadir, Ebusus y la influencia púnica en los territorios hispanos. VIII Jornadas de Arqueología fenicio-púnica, Ibiza, 59-74.

- (2000): "Panorama arqueológico de la Hispania púnica a partir de la época bárquida", García-Bellido, $\mathrm{M}^{\mathrm{a}} \mathrm{P}$. y Callegarin, L. (coords.), Los cartagineses y la monetización del Mediterráneo Occidental, Anejos de Archivo Español de Arqueología XXII, 75-88.

Berthier, A. et Charlier, R. (1955): Le sanctuaire punique d'El-Hofra à Constantine, Paris.

CAMPo, M. (1993): "Emisión de Emporion con tipología ateniense", Actes du Xiéme Congrès International de Numismatique, Lovain-la-Neuve, 31-38.

- (1994): "Moneda griega y púnica de Hispania: las primeras emisiones", Actas del IX Congreso Nacional de Numismática, Elche, 75-79.

- (2003): "Les primeres imatges gregues: l'inici de les fraccionàries d'Emporion", Les imatges monetàries: llenguatge $i$ significat, Barcelona, 25-45.

Corzo, R. y Toscanos, M. (1992): Las vías romanas de Andalucía, Sevilla.

CRAWFORD, M.H. (1985): Coinage and money under the Roman Republic, Londres.

Chaves Tristán, F. (2000): “¿La monetización de la Bética desde las colonias púnicas?”, García-Bellido, $\mathrm{M}^{\mathrm{a}}$ P. y Callegarin, L (eds.), Los Cartagineses y la monetización del Mediterráneo Occidental, Anejos de Archivo Español de Arqueología XXII, 113-126.

- (2003): "De la imagen y la palabra. Monedas en la Hispania Antigua”, Les imatges monetàires: llenguatge $i$ significat, Barcelona, 9-24.

Chaves Tristán, F. y García Vargas, E. (1991): "Reflexiones en torno al área comercial de Gades: estudio numismático y económico", Gerion, Homenaje al Dr. Michel Ponsich, 139-168.

- (1994): "Gadir y el comercio atlántico a través de las cecas occidentales de la Ulterior”, Arqueología en el entorno del Bajo Guadiana, Huelva, 375-392.

- (1996): "Los tesoros en el Sur de Hispania". Conjuntos de denarios y objetos de plata durante los siglos II y I a.C., Sevilla.

Chaves Tristán, F.; García Vargas, E. y Ferer AlbeldA, E. (1998): "Datos relativos a la pervivencia del denominado "Círculo del Estrecho" en época republicana”, L’Africa romana, 1308-1320.

Chaves Tristán, F. y Marín Ceballos, M.C. (1979):”El elemento religioso en la amonedación hispánica antigua", IX Congreso Internacional de Numismática, Berna, 657-671.
Domínguez Monedero, A. (1987): "Los libio-fenicios y la interpretación del significado de su presencia en el Sur Peninsular", Actas del I Congreso HispanoAfricano de las culturas del Mediterráneo Occidental, Granada, 129-138.

(1995): "De nuevo sobre los "libiofenicios": un problema histórico y numismático", García-Bellido, $\mathrm{M}^{\mathrm{a}} \mathrm{P}$. y Sobral Centeno, R.M. (eds.), La moneda hispánica. Ciudad y territorio, Anejos de Archivo Español de Arqueología XIV, 111-116.

(2000): "Monedas e identidad étnico-cultural de las ciudades de la Bética", García-Bellido, M ${ }^{\mathrm{a}}$ P. y Callegarin, L. (coords.), Los cartagineses y la monetización del Mediterráneo Occidental, Anejos de Archivo Español de Arqueología XXII, 59-74.

Fernández Chicarro, C. (1947): "Adquisicio-nes del Museo Arqueológico Provincial de Sevilla", Memoria de los Museos Arqueológicos Provinciales, 156 ss.

FERnÁNDEZ Nieto, F.J. (2002): "Hemeroskopeion = Thynnoskopeion. El final de una problema histórico mal enfocado", Colonizadores e indígenas en la Península Ibérica, Mainake XXIX, Málaga, 231-255

GarcíA-Bellido, M M P. (1992): "La moneda, libro en imágenes de la ciudad", La sociedad ibérica a través de la imagen, Madrid, 237-249.

- (1993a): "Las relaciones económicas entre Massalia, Emporion y Gades a través de la moneda", Huelva Arqueológica XII, 115-149.

- (1993b): “Origen y función del denario ibérico", Sprachen und Schriften des Antiken Mittelmeerraums. Fetschift für J. Untermann, Innsbruck, 97-115.

(1995): "Célticos y púnicos en la Beturia según sus documentos monetales", Celtas y Túrdulos: la Beturia, Mérida, 255-292

- (1999): "Notas numismáticas sobre los berones y su territorio", Actas del VII Coloquio sobre lenguas y culturas paleohispánicas, Zaragoza-Salamanca, 203-220.

- (2000): "La relación económica entre la minería y la moneda púnica en Iberia”, García-Bellido, M ${ }^{\mathrm{a}} \mathrm{P}$. y Callegarin, L. (coords.), Los cartagineses y la monetización del Mediterráneo Occidental, Anejos de Archivo Español de Arqueología XXII, 127-144.

- (2001): "Numismática y etnias: viejas y nuevas perspectivas", Religión, Lengua y Cultura prerromanas de Hispania, Salamanca, 135-160.

- (2002a): "Los primeros testimonios metrológicos y monetales de fenicios y griegos en el sur peninsular”, Archivo Español de Arqueología 75, 93-106.

- (2002b): "Los ponderales y sus funciones económica y religiosa", Celestino, S. (ed.), Cancho Roano IX. Los 
Materiales Arqueológicos II, Madrid, 127-155.

García-Bellido, M ${ }^{\mathrm{a}}$ P. y BlázQuez, C. (1995): "Formas y usos de las magistraturas en las monedas hispánicas”, García-Bellido, M ${ }^{\mathrm{a}}$ P. y Centeno, R.M.S. (eds.), La moneda hspánica. Ciudad y territorio, Anejos de Archivo Español de Arqueología XIV, 381428.

(2001): Diccionario de cecas y pueblos hispánicos, Madrid.

GarcíA-Bellido, M M ${ }^{\mathrm{a}}$ P. y Ripollès, P.P. (1998): "La moneda ibérica: prestigio y espacio económico de los iberos", Los iberos. Príncipes de Occidente, Barcelona, 205-215.

García Vargas, E. (2000): "Pesca, sal y salazones en las ciudades fenicio-púnicas del sur de Iberia", De la mar y de la tierra. Producciones y productos fenicio-púnicos. XV Jornadas de Arqueología fenicio-púnica, Ibiza, 966.

García Vargas, E. y Ferrer Albelda, E. (2001): "Las salazones de pescado de la Gadir púnica. Estructuras de producción”, Laverna XII, 21-41.

Hours-Miedan, M. (1951): "Les représentations figurés des stèles de Carthage", Cahiers de Byrsa 1, 15-160.

KNAPP, R. (1977): "The date and purpose of the Iberian Denari”, Numismatic Chronicle 17, 1-18.

KraAY, C.M. (1976): Archaic and Classical Greek Coins, Londres.

KROLL, J. (1981): "From Wappenmünzen to Gorgoneia to Owls", Museum Notes 26, 1-32.

Lavado Florido, M ${ }^{\mathrm{a}}$ L.; Perdigones Moreno, L.; Aguilera Rodríguez, L. Y Jiménes Pérez, C., 1990: "III Campaña de excavaciones arqueológicas en el yacimiento de Carisa Aurelia. Espera-Bornos (Cádiz)", Anuario Arqueológico de Andalucía 1987. II. Actividades de Urgencia, Sevilla, 117-125.

Lavado Florido, M ${ }^{\mathrm{a}}$ L. y Perdigones Moreno, L. (1990): "IV Campaña de excavaciones arqueológicas en la necrópolis romana de Carisa Aurelia (Espera-Bornos, Cádiz)", Anuario Arqueológico de Andalucía 1988. III. Actividades de Urgencia, Sevilla, 113-119.

MANFREDI, L.I. (1985): "RSMLQRT, R SMLQRT: Notta sulla numismatica punica di Sicilia”, Rivista Italiana di Numismatica e Scienze affini 87, 3-8.

- (1987-88): "Moneta e valori pondierali fenici a Kition", RSQ LXI, 1-4, 81-87.

-(1987): "Melqart e il tonno", Studi di Eggitologia e di Antichità Puniche, 67-88.

Marín Ceballos, Mª C. (2002): "En torno a las fuentes para el estudio de la religión fenicia en la Península
Ibérica”, Ferrer Albelda, E. (ed.), Ex Oriente Lux: las religiones orientales antiguas en la Península Ibérica, Spal Monografias II, 11-32.

Melchor Gil, E. (1999): "La red viaria romana y la comercialización de los metales de Sierra Morena", Centeno, R.M.S.; García-Bellido, Mª P. y Mora, G. (coords.), Rutas, ciudades y moneda en Hispania. Anejos de Archivo Español de Arqueología XX, 311322.

Mora Serrano, B. (1999): "La circulación monetaria en la ciudad de Acinipo (Ronda, Málaga) y las comunicaciones entre el Estrecho y el Valle del Guadalquivir", Centeno, R.M.S.; García-Bellido, $\mathrm{M}^{\mathrm{a}}$ P. y Mora, G. (coords.), Rutas, ciudades y moneda en Hispania. Anejos de Archivo Español de Arqueología XX, 341-348

Olmos, R. (1992): "Iconografía y culto a las aguas de época prerromana en los mundos colonial e ibéricos", Termalismo Antiguo. Espacio, Tiempo y Forma serie II, 5, 103-120.

Oria Segura, M. (1996): Hércules en Hispania: una aproximación, Barcelona.

- (2002): "Religión, culto y arqueología: Hércules en la Península Ibérica", Ferrer Albelda, E. (ed.), Ex Oriente Lux: las religiones orientales antiguas en la Península Ibérica, Spal Monografías II, 219-244.

Pena, Ma J. (1973): "Artemis-Diana y algunas cuestiones en relación con su iconografía y culto en Occidente", Ampurias 35, 109-134.

Pérez Almoguera, A. (1996): "Las cecas catalanas y la organización territorial romano-republicana", Archivo Español de Arqueología 69, 37-56.

Perdigones Moreno, L.; Molina Carrión, M. y Rojo Corrales, A. (1987): "Excavaciones de urgencia en Carisa Aurelia 1986. Segunda Campaña, Anuario Arqueológico de Andalucía 1986. III Actividades de Urgencia, Sevilla, 67-74.

Presedo Velo, F.J.; Muñiz Coello, J.; Santero SAnturino, J.M ${ }^{\mathrm{a}}$ y Chaves Tristán, F. (1982): Carteia I, Excavaciones Arqueológicas en España 120, Madrid.

Quesada, F. y García-Bellido, Mª P., 1995: "Sobre la localización de ikale(n)sken y la iconografía de sus monedas", García-Bellido, M ${ }^{\mathrm{a}}$ P. y Sobral Centeno, R.M. (eds.), La moneda hispánica. Ciudad y territorio, Anejos de Archivo Español de Arqueología XIV, 6574 .

RIPOLlÈs, P.P. (1989): "Fraccionarias ampuritanas. Estado de la investigación”, Archivo de Prehistoria Levantina 19, 303-317.

Ripollès, P.P. y Llorens, Ma M. (2002): Arse-Saguntum. 
Historia monetaria de la ciudad y su territorio, Valencia.

Rodríguez NeILA, J.F. (1995): “Organización administrativa de las comunidades hispanas y magistraturas monetales", García-Bellido, M ${ }^{\mathrm{a}}$ P. y Centeno, R.M.S. (eds.), La moneda hspánica. Ciudad y territorio, Anejos de Archivo Español de Arqueología XIV, 261316.

- (2000): "Sociedad indígena y génesis de las élites municipales en Hispania”, Salvador Ventura, F. (ed.), Hispania meridional durante la Antigüedad, Jaén, 147182.

SÁez Romero, A. (2004): "El alfar tardopúnico de Torre Alta. Resultados de las excavaciones de 2002-03", Actas del Congreso Internacional Figlinae Baeticae, B.A.R. int. ser., Oxford.

SANMARTí, E. (1989): "Emporion, port grec a vocation iberique", La Magna Grecia e il lontano Occidente. Atti XXIX Convegno di studi sulla Magna Grecia, Tarento, 389-410.
Sillières, P. (1990): Les voies de communication de l’Hispanie Méridionale, París.

VILLARONGA, L. (1980): "La drachme ibérique iltirkesalir et les rapports avec la Grande Grèce au IIIes. J.C.”, Revue Numismatique 22, 43-56.

- (1983): Les monedes ibèriques de Tàrraco, Barcelona.

- (1984): "Las primeras emisiones de bronce en Hispania”, Blagg, T.F.C. et alii (eds.), Papers in Iberian Archaeology (BAR Int.Ser. 193,1), Oxford, 205-215.

- (1985): "El tesorillo de Carisia" III Congreso Nacional de Numismática, 569-583.

- (1994): Corpus Nummum Hispaniae ante Augusti aetatem, Madrid (citado en texto como CNH).

- (1997): Monedes de plata emporitanes dels segles V-IV a.C., Barcelona.

- (1998): Les dracmes ibèriques i llurs divisors, Barcelona. 